tribunal be male and that one be a member of the Society of the Holy Cross, a clerical society in the catholic tradition in the Church of England. He alleged that the substance of the case in its initial stages rested on his opposition to the ordination of women to the priesthood. He raised the question of whether the complaint against him was a pretext for removing him from office because of his views on women priests and suggested that a woman priest could not be sufficiently impartial towards him. The President of Tribunals rejected this application. The tribunal noted that the complaint was not about the respondent's views on the ordination of women and that it was not open to him to challenge the validity of the appointment of a woman priest to the tribunal. It was incumbent on the tribunal, however, by reason of Article 6 of the European Convention on Human Rights, to consider any lack of impartiality levelled against it. The tribunal did so and unanimously found that there was no violation. The respondent did not attend the hearing and the tribunal proceeded in his absence. The complaint having been proved, a seven-year prohibition was imposed. [WA] A transcript of the tribunal's determination may be found at http://www.ecclaw.co.uk/ clergydiscipline/gair1.pdf and of the imposition of penalty at http://www.ecclaw.co.uk/ clergydiscipline/gair2.pdf

doi:10.1017/So956618Xo9002178

\title{
Re St Mary, Wollaston
}

Peterborough Consistory Court: Pulman Dep Ch, November 2008 Re-ordering - removal of pews

The vicar and churchwardens, with the unanimous support of the PCC, sought a faculty for a major re-ordering of the Grade II* listed church. There was general agreement between the PCC, the DAC and the amenity societies on the scope of much of the proposed re-ordering. However, the Church Buildings Council and English Heritage opposed the removal of pews and their base platforms from the nave and their replacement with chairs. The pews were late Victorian but incorporated the doors from Georgian pews re-used as pew-ends. These were of historical significance. The petitioners proposed not to dispose of the pew ends but to re-use them in a re-built west-end gallery. The chancellor noted that the question of the removal of the pews needed to be resolved first, as the scheme for the rest of the building would need to be different if the pews were not to be replaced. He accepted that the full, final costing of the scheme could not be presented, as it would be disproportionate to produce two fully costed alternative schemes. 
The chancellor reviewed the law on re-ordering, including the question of necessity, citing Re St Helen, Bishopsgate, Re St Mary the Virgin, Sherborne, Re St John the Evangelist, Blackheath and Re All Saints, Burbage. ${ }^{5}$ He noted that the worshipping community wholeheartedly supported the proposal and that the local community voiced no opposition. The chancellor found that, while the removal of the pews would adversely affect the character of the building, the effect would only be of marginal significance and be mitigated by the proposed re-siting of the pews in the gallery. A faculty was granted. [WA]

\section{Eweida v British Airways plc}

Employment Appeal Tribunal: Elias J, November 2008

Religious dress - cross - employment - discrimination

The former uniform policy of British Airways was that employees who wished to wear a visible religious item were only permitted to do so if the item was doctrinally mandatory, could not be concealed under the uniform and had been approved by management. This meant that the claimant was not permitted to wear a cross that was visible on her uniform. She alleged that this constituted direct and indirect discrimination and harassment on grounds of religion or belief, contrary to the Employment Equality (Religion or Belief) Regulations 2003, SI 2003/1660. The Employment Tribunal dismissed her claims. ${ }^{6}$

The claimant's appeal focused solely upon the tribunal's finding that there had been no indirect discrimination. Before the Employment Appeal Tribunal, the claimant contended that the Employment Tribunal had erred in law in finding that the policy did not put Christians at a particular disadvantage. The claimant submitted that the tribunal had erred in finding that there was no evidence that there was a significant number of persons in addition to the claimant who had suffered a 'particular disadvantage'. Even if relatively few people were prepared to go as far as she did in refusing to comply with the policy, there would certainly be some who would object on religious grounds to it, while choosing reluctantly to comply with it. It was submitted that a 'particular disadvantage' could be suffered even where the employee can and does comply with the provision. The EAT noted that, although it was doubtful whether the case was advanced on this basis before the tribunal, there was some merit in this

5 Re St Helen, Bishopsgate (1993) 3 Ecc LJ 256, London Cons Ct; Re St Mary the Virgin, Sherborne [1996] Fam 63, [1996] 3 All ER 769, Ct of Arches; Re St John the Evangelist, Blackheath (1998) 5 Ecc LJ 217, Southwark Cons Ct; Re All Saints, Burbage (2007) 9 Ecc LJ 345, Salisbury Cons Ct.

6 The Employment Tribunal decision is noted at (2008) 10 Ecc LJ 256. 